\title{
MEMORY IN THE WORK OF CARYL PHILLIPS: SANCTUARY AND/OR PRISON? ${ }^{1}$
}

Memory and rememoration were crucial for the (re)construction of postcolonial identities in the heyday of historical and cultural retrieval in earlier postcolonial literature. With the gradual change of focus towards considerations of identity construction in neocolonial societies, the importance of rememoration faded while memory continues to haunt characters in contemporary postcolonial fiction, as Caryl Phillips's writing illustrates. His protagonists retrace memories of past lives, seeking refuge from loss, exile and marginalization, risking permanent entrapment in the labyrinths of past traumas. Although withdrawal into memory prevents some of them from adapting to their surroundings, memory in Phillips's work as a whole serves as a meeting point for pogrom survivors. It is a polyphonic, heterotopian, heterogeneous imaginary community to which the uprooted figures of his novels belong. The aim of this article is to examine the function of memory in Phillips's vision, arguing that the established space of memory is designed to mend the rift between value-infested polarities.

Keywords: Caryl Phillips, history, memory, postcolonial, rememoration.

\section{CONTEXTUALIZING PHILLIPS'S PREOCCUPATION WITH MEMORY}

Memory as an essential instrument for the preservation of one's identity (Halpern, 2009: 31) and rememoration as an articulation of silenced pasts play a vital, yet ambiguous, role in the (re)construction of postcolonial identities. Both are crucial for the retrieval of lost or denied histories and precolonial cultures, contributing to the establishment of links with them and ensuring imagined or imaginary continuity. Their position is ambiguous, though, as precolonial histories and cultures cannot be retrieved in their untainted form, but also because of the danger of falling into the trap of nostalgia or of what Salman Rushdie calls "ghetto mentality" (Rushdie, 1992: 19). Memory and rememoration are particularly relevant for early postcolonial literature, of which Chinua Achebe is a prime example, which served to rival history as a "scientific' view of the past", or "a simple representation of the continuity of events" (Ashcroft, Griffiths, \& Tiffin,

Arijana Luburić Cvijanović, alcvijanovic@ff.uns.ac.rs. The first draft of this paper was presented at the conference The Politics of Memory: Re-Thinking Humanities and Social Sciences in Zadar, Croatia. 
2003: 355) and an instrument for controlling non-Europeans. In this sense, fiction deconstructs history's representations offering, according to J.M. Coetzee among others, alternatives. As Achebe's novel Things Fall Apart shows, this is most important in cultures where Europeans imagined darkness or chaos before their arrival; fiction, or all literature for that matter, can then serve to counteract such views.

Although some postcolonial literature - the part of it that employs "post" as "anti" - still takes on the complex task of questioning historical, especially colonial, representations, there has been a gradual shift of focus away from historical and cultural retrieval, towards examinations of identity within the context of postcolonial hybridity in the increasingly globalized and urbanized neocolonial world. Hence, rememoration and, to an extent, memory sometimes cease to be among the prevailing leitmotifs and significant driving forces in postcolonial fiction. However, memory still seems to provide a shaky foundation for the construction of unstable, fluid and fragmentary identity in some contemporary postcolonial works, displaying a tendency which Caryl Phillips's work amply testifies to.

As Phillips was born in the Caribbean, one might be tempted to relate his interest in memory to the long history of colonization and the slave trade which created a syncretic population whose ancestry originates in Africa, Europe, India, China and the Middle East, weaving a narrative of displacement. It is precisely because the multiethnic Caribbean population is made up of descendants of both those who voluntarily moved there and those who were taken from their homelands by force that memory is a key to the understanding of Caribbean literatures. However, in many of its aspects Phillips's work draws less from Caribbean sources than from European ones, so it makes more sense to view his writing in its UK context, namely, the writing of the Caribbean diaspora and what is commonly yet indeterminately called Black British literature.

To an extent, Phillips's novels follow a shift in the writing of the Caribbean diaspora in the UK. Like the works of the first Caribbean migrants, his early novels thematize the hardships and disappointments of early immigrants and returnees, demythologizing both homelands and host cultures, while simultaneously problematizing the conflict between tradition and modernity, communalism and individualism, or spirituality and rationality (King, 2004: 32). Later novels by Caryl Phillips mark a gradual turn towards metropolitan realities, searching for their own means to represent the peculiarities of migrant experiences in England and shedding light on the complex problematics of diasporic life: racial and class discrimination, alienation, or obsession with accommodation as a symbol for "belonging and inheritance", with difficulties in finding one reflecting a sense of insecurity in England (King, 2004: 44). Such issues inspire critics like Bruce King to place Phillips's work within the loosely defined black British literature whose porous boundaries raise a number of problems. Can Hanif Kureishi's half-English, half-Indian origins justify his being classified as a founder of black British theatre? 
If this scene differs from West Indian theatre, why is Phillips seen as a founder of the former? Is it advisable to homogenize the diverse experiences of African and Caribbean migrants of different classes, ethnicities or gender? These and similar questions inspire debates over the appropriacy of such generalizing terms, prompting Phillips to deny the existence of a black British literary tradition and doubt the existence of a black literary tradition in English, with the exception of the African American one (Schatteman, 2009: 101). Speaking of traditions, Phillips also questions the Anglophone Caribbean prose which in his opinion has "gone a long way towards defusing the tradition" (Schatteman, 2009: 101).

Whichever context one chooses as an interpretative lens for Phillips's writing, his prose transcends it by moving away from purely Caribbean, Black British, or even postcolonial concerns, in that his migrants are not only Caribbean, African, black or postcolonial. Despite a certain thematic similarity, with memory as an undisputedly significant motif in all the potential frameworks of analysis, Phillips's fiction establishes further differences from the writing of the Caribbean diaspora or that of black British authors, in which he sees no continuity. His structures and forms are known to have been influences by jazz and soul rather than Caribbean sounds like the Trinidadian calypso, and dialogue with the past and present is not conducted in the specific creolized "english", a polydialectic Creole continuum (Ashcroft et al., 2002: 44) which some among Phillips's protagonists use, while standard English prevails in his polyglossic oeuvre. For these and a host of other reasons which will be mentioned further in the text, it is perhaps best to contextualize Phillips's concern with memory across borders of nation, ethnicity, race, culture or literary category.

\section{PHILLIPS'S CHORUS OF COMMON MEMORY}

If the past is "a country from which we have all emigrated", its loss being "a part of our common humanity" (Rushdie, 1992: 12), then the migrant, an epitome of the modern era of incessant migrations, has migrated both temporally and spatially. The significance of memory for the migrant figure is, therefore, amplified by the loss of both the past and the home country. As a British author of Caribbean origins who has lived in Britain, the US and, for a while, the Caribbean, Caryl Phillips has experienced this double loss and feels that his sense of belonging is "still in flux" (Scahtteman, 2009: 95). In view of that, his constant preoccupation with memory emphasizes it as a bridge between the here and now, on one hand, and one's past, roots and homelands turned into mythical lands and imaginary spaces, on the other. His own memory of his two homes, the Caribbean and a more distant one, Africa, and the themes of migration, loss and belonging, have supplied his writing with what can, and perhaps should, be interpreted as its vital lifeline.

If memory is its lifeline, Phillips's work may be seen as an act of rememoration since his characters, from a wide variety of backgrounds, seem endlessly 
preoccupied with and haunted by the memory of untold pasts. In need of some form of refuge from the harsh realities of displacement and ostracism, Phillips's protagonists follow or are persecuted by memories of past lives, disclosing hidden narratives of trauma. Even though some among them become hopeless prisoners of memory, which renders them inadequate to engage in satisfactory communication with their surroundings, memory in Phillips's oeuvre also provides a space which summons and shelters the anonymous masses of persecution survivors.

Without ever attempting to homogenize their experiences while exploring parallels in them, Phillips concentrates on members of the Jewish and African diasporas, Jews in 15th-century Venice and the Second World War, (former) slaves and their descendants in the Old and New World, as well as white women in patriarchal and/or gender-biased societies, like Emily from Cambridge, Joyce from Crossing the River, or Dorothy from A Distant Shore. In the words of Helen Thomas, the "exposure of such parallels and differences not only works towards a recovery of a past heritage, but also underlines the dynamic interactions between the past and the present" (Thomas, 2006: 3) in the lives of characters who are invariably traumatized by racial, ethnic, gender, class and other inequalities, with the disrupted narrative structures mirroring their disrupted lives, as in Higher Ground, The Nature of Blood, Crossing the River, and A Distant Shore.

A retreat for many and persecutor for some, memory plays a critical part in all their life stories. Memory of the slave trade, as depicted in Cambridge, Higher Ground and Crossing the River, is reflected in the racially and ethnically biased British and American societies in the second half of the 20th century. In Higher Ground, for instance, a brutally mistreated African-American prisoner in the 1960 s descends into madness as he gradually establishes continuity between himself and his enslaved ancestors, imagining himself as a slave. His chapter, symbolically entitled "Cargo Rap", continues the centuries-long narrative of racial discrimination and its far-reaching consequences, his rant echoing slave chants - "I have sung to you a little cargo rap about the children of Africa who arrived in this country by crossing the water" (Phillips, 1999: 154).

Rudy begins a series of letters that chronicle the weakening of his emotional and mental stability by addressing his parents, who are "malprogrammed in a hostile and alien culture" (Phillips, 1999: 64) to think their inferiority is natural and serve white people, oblivious to the chains that restrain them, now invisible but very real. Unable to conceive of any positive contact between black and white people - in his parents he sees a whole generation dulled into passivity and acquiescence, or "slave mentality" (Phillips, 1999: 64), and in himself a victim of maltreatment which deprives one of basic humanity - he feels exiled in America, dreams of a return to Africa, and relates through collective memory to African slaves in the delusion of having become one. Despite all the brutalities he suffers in prison, Rudy states that his occupation is "Survivor" (Phillips, 1999: 91) and, overstepping spatial and temporal boundaries, Rudy imagines himself belonging 
to a long line of survivors - he conceives of himself as being between 200 and 300 years old - establishing in memory an entire community of victims, so his prison guards are at the same time "the overseer", "the master", "KKK types", and "the Gestapo Police", the ship taking Richard Wright from America to France is "SS United States", and Rudy's prison is envisioned as both "the plantation" and "Belsen" (Phillips, 1999: 84, 127, 140, 172). The imagined community is thus shown as equally accepting of African slaves, African-American targets in "the American sport of "nigger-lynching"' (Phillips, 1999: 64), and victims of the Holocaust.

That Rudy's and his ancestors' victimization is a mirror-image of the persecution of Jews is also suggested in the stories of Irina from Higher Ground and Eva from The Nature of Blood. Irina is a doubly marginalized Polish refugee in England, haunted by memories of her past life which torture her but also provide shelter from unwelcoming foreign surroundings. Endlessly crying, talking to herself, thinking no good person exists, and obsessed with thoughts of death and God's punishment, Irina endures extreme loneliness in isolation as each one of her few attempts at adapting to life in England fails. This failure is partly due to her reluctance to possess anything - "Her fear was that she doubted if she would ever again have the strength to want to possess" (Phillips, 1999: 190) - as she lost everything in the past, then her general distrust of people, especially after having been committed to a mental institution, and finally, her immersion in memory, kept alive in dreams which, like those of Gabriel/Solomon in A Distant Shore, contain untold stories of her life before England and her past self. Moreover, they reveal a deeply cherished desire to go back or find home - "In her dream Irene always made her way back to the house which held the room that she called "home" (Phillips, 1999: 216). Shy, reserved, socially awkward and utterly friendless among unfriendly strangers who rename her into Irene and refer to her as a "crazy Polish bitch" (Phillips, 1999: 218), Irina clings to memory as the only thing left to her in this world. Unable and unwilling to adapt and/or murder memory (Phillips, 1999: 24) of the lost homeland, family, and self - "I can't forget Irina", says she (Phillips, 1999: 217) - she remains a prisoner of her own deranged mind.

Irina's counterpart, Eva Stern, a wary and paranoid death camp survivor relating her life before, during and after the Holocaust, cannot escape memories of degradation, humiliation and horrors of concentration camps. In them, the inmates first attempt to preserve their old identities for a better future but later, dehumanized and animal-like, deprived of their families, dignity and humanity, they face what will prove to be a futile "task of forgetting" (Phillips, 1998: 13). After liberation, Eva struggles with "the violence of memory" (Phillips, 1998: 13), suffering from "loyalty to the dead" (Coetzee, 2002: 196). In England, where she attempts to reconstruct her shattered life but does not feel at home - "'Home' is a place where one feels a welcome." (Phillips, 1998: 37) - a psychiatrist's diagnosis states: "To move on is to forget. To forget is a crime" (Phillips, 1998: 157). Suffering and memory become her only "possessions" and the only emblems of 
her identity. For her and her co-sufferers - Jewish money lenders persecuted in 15th-century Venice and Falashas in 20th-century Israel from The Nature of Blood, all of whom find a "home" in the tradition (Halpern, 2009: 266-267), or slaves and migrants in Phillips's other novels - memory, "[t] hat untidy room with unpredictable visiting hours" (Phillips, 1998: 11) which brings madness to some but comfort to others, becomes the only space of belonging, a temporal, not spatial homeland (Ledent, 2002: 146) in the "temporal territory of Tradition" (Bhabha, 2003: 300).

Three voices in the polyphony of Phillips's novels demonstrate a willingness to displace memory, Othello whose temporarily dislocated memory is that of Africa and his African family in The Nature of Blood, Solomon who suppresses memory of himself and his life as Gabriel in A Distant Shore, and his elderly neighbour Dorothy who endeavors to forget a failed marriage and painfully dysfunctional family relations. They make an effort to forget who they once were so they could reinvent themselves and start anew, Dorothy and Solomon in a seemingly quiet village neighbourhood in England, and Othello in the centre of the Venetian empire.

Driven by the need to be appreciated by the Venetian high society, Othello sees his marriage to Desdemona as a step towards that goal, wondering if "a marriage of the finest of my own customs with their Venetian refinement might not, in due course, produce a more sophisticated man" (Phillips, 1998: 120), in other words, make him more civilized, thereby transferring him from the margins to the centre. In spite of his internalization of western prejudices against him as an ethnic or racial "other", Othello cannot escape the inner voice calling him back to Africa, where he enjoys respect and dignity. His marriage to Desdemona problematizes the issue of his return to his native country and potentially implies a severing of all ties with his life in Africa. However, feelings of isolation and loneliness Othello finds a kind of companionship only among the Jews of the Venetian ghetto, the first quarter in the world to be called that - feed a sense of guilt over his act of abandonment. Namely, the voice of memory keeps reminding him of his "native wife" who is not a "wife in the manner that a Venetian might understand the term" (Phillips, 1998: 146), and the son he has left behind. His attempt to begin a new life among foreigners proves to be a failure as he cannot silence memory that first mockingly reprimands him and then gently calls him home.

You tuck your black skin beneath their epauletted uniform, appropriate their words $[\ldots]$, their manners, worry your nappy woollen head with anxiety about learning their ways, yet you conveniently forget your wife and son to the back of your noble mind. [ ... ] You are lost, a sad black man, first in the long line of so-called achievers who are too weak to yoke their past with their present; too naïve to insist on both; too foolish to realize that to supplant one with the other can only lead to catastrophe (Phillips, 1998: 180-181). 
My brother, an African river bears no resemblance to a Venetian canal. Only the strongest spirit can hold both together. Only the most powerful heart can endure the pulse of two such disparate life-forces. [ ... ] Did you truly ever think of your wife's soft kiss? Or your son's eyes? Brother, you are weak. A figment of the Venetian imagination. While you still have time, jump from her bed and fly away home (Phillips, 1998: 182).

There is no home to which the voice of memory could summon Solomon, the silent, enigmatic male protagonist of Phillips's novel A Distant Shore. Solomon displaces memory out of the need to forget the war massacres which took the lives of his family in Africa, as well as the snubbing and outright harassment he experiences in England. To remake himself, he knows he needs to "learn to banish all thought of his past existence" (Phillips, 2004: 94), so to that end he migrates to England, leaving behind the horrors of the tribal war. In the words of a fellow migrant, he wants to "forget Africa and those people" and be "an Englishman now" (Phillips, 2004: 134). His torturous journey - they travel "like cargo" (Phillips, 2004: 94), echoing the life journeys of Rudy and their enslaved ancestors - and disappointing life in England, marked by imprisonment, not unlike that of Rudy, due to false rape allegations, difficulty in finding work and adapting to a hostile environment, prove a poor substitute as he escapes one form of violence only to find another. His obstinate hope for a reconstructed life is symbolized by his change of name from Gabriel to Solomon, but the nurturing wisdom implicit in the chosen biblical name offers no help in dealing with or deconstructing stereotypes which England has of him. That is effectively why Solomon's attempt to comfort a girl who helps him despite her vulgarity, disrespect and lack of decency, goes misinterpreted and he ends up in prison where he temporarily suffers from a form of repressed memory syndrome which erases all knowledge of the girl. To improve his situation, "he knows that at some point in the future he will probably have to start to remember about the girl, but he is not ready. Not yet." (Phillips, 2004: 118)

Once he is free, Solomon rebuilds his lonely life but never mentions his family or homeland, his house breathes a conspicuous absence of photographs or any other objects that would hint at his past, and his obsessive car washing is interpreted by Dorothy as follows: "His every movement would appear to be an attempt to erase a past that he no longer wishes to be reminded of." (Phillips, 2004: 268) However, dreams keep tormenting him, confronting him with a sense of guilt "my dreams were permanently cursed with the accusatory faces of my parents" (Phillips, 2004: 279) - disclosing what he refuses to talk about - "My dreams contained my history." (Phillips, 2004: 297) The nightmares show that Gabriel can flee Africa, but Solomon cannot flee from Gabriel, whose presence forces England to remember its imperial past since his is one of the many hidden (hi) stories of the nation. The contrapuntal narrative structure in A Distant Shore reveals another suppressed (hi)story as Dorothy moves to a new place, symbolical of a new beginning, to erase the memory of her unsuccessful marriage and family 
relations, particularly the painful relationship with her sister Sheila. Dorothy pushes back the memory of Sheila's death, thinking at one point "maybe Sheila and I can go abroad together" (Phillips, 2004: 60), to avoid facing her long-felt guilt over a lack of support for her sexually abused lesbian sister. Memory haunts her though, in the form of her now "imaginary Sheila who likes me and still needs my help" (Phillips, 2004: 71). As a result, Dorothy loses touch with reality which, coupled with her loss of dignity, places her in line with Rudy, Irina and Eva, characters reminiscent of those of W. G. Sebald in being "burdened with hidden history" (Phillips, 2004: 300), persecuted by dreams that "come thick and fast", and caught between "a self-protective urge to block off a painful past and a blind groping for something [ ... ] that has been lost" (Coetzee, 2008: 146).

This vacuum occupied by Phillips's protagonists sheds light on the gaps between individual memory, collective memory, and official history, bringing to the surface strategies of selection and exclusion. The intricate play between selection and erasure, fact and fiction is best exemplified in Cambridge through a juxtaposition of the official report of an overseer's murder, and the alleged murderer's memory of the event. The accused's given name, Cambridge, symbolical of his education and manners, yet tinged with irony as universities were places which gave scientific foundations to or justification of prejudice, sharply contrasts this slave's bearing with white people's belittling views of his race. Compared to white Emily's almost 130-page-long account, some 40 pages related from Cambridge's point of view provide little space for his stunning eloquence, highlighting the idea that history for the most part ignored testimonies of the muted "other". Continuing the paradigm set by Defoe in Robinson Crusoe - a native is brought into the light of civilization by being renamed and taught English and the word of God - only to reverse it, Cambridge's narrative not only contests the many stereotypes about non-whites' presumed inferiority in Emily's story, but also questions the truthfulness of historical documents. To be effectively subversive without resorting to personal judgment, Phillips sets memory and a written document against each other, allowing them to speak for themselves. While memory's account reveals a history of unspeakable and uncalled-for brutalities experienced by Cambridge and his wife at the hands of "a bullying brute of an overseer who seemed trapped within the imagined swaggering authority of his own skin" (Phillips, 1993: 161), the historical report of the murder (in self-defense) falsely presents Cambridge as an "insane man", unsuitable for "a life of moral and domestic responsibility" (Phillips, 1993: 171-172), whose murderous intentions eventually rid the overseer of his life. By contrast, the document, every sentence of which leaks exaggeration, paints a hardly credible portrait of Brown as a just overseer and a devout Christian soul who "carried on an innocent amour with a woman belonging to his property" (Phillips, 1993: 171), Cambridge's wife.

A similar juxtaposition is found in the novel Crossing the River, where a father's excruciating memory of his desperate act of selling his children is placed in opposition with the trader's factual notes of the purchase in his log-book. 
A desperate foolishness. The crops failed. I sold my children. I remember. I led them (two boys and a girl) along weary paths [... Returned across the bar with the yawl, and prayed a while in the factory chapel. I watched as they huddled together and stared up at the fort, above which flew a foreign flag. Stood beneath the white-washed walls of the factory, waiting for the yawl to return and carry me back over the bar. In the distance stood the ship into whose keep I will soon condemn them. The man and his company were waiting to once again cross the bar. We watched a while. And then approached. Approached by a quiet fellow. Three children only. I jettisoned them at this point, where the tributary stumbles and swims out in all directions to meet the sea. Bought two strong man-boys, and a proud girl. I soiled my hands with cold goods in exchange for their warm flesh. [ ... ] I believe my trade for this voyage has reached its conclusion (Phillips, 1995: 1).

This lengthy quote serves to illustrate not only Phillips's wish to contrast the official and unofficial narratives of history and memory, but his overwhelming interest in memory's truth - the log-book records factual details of a history, but they are fragments of the trader's perception and memory of the events described. In this novel, as in all his other fictional works, Phillips offers stories the west would rather forget, challenging the concepts of selection and exclusion, and asserting the power of memory. The sold children's voices soon join a "chorus of a common memory" (Phillips, 1995: 1) whose unforgettable chant comprises innumerable stories of fractured lives of all those who, the novel's dedication states, crossed the river.

Phillips's chorus of common memory metaphorically encapsulates his entire work, corresponding to Toni Morrison's idea of Black Americans' or, by extension, all black people's rememoration through art, especially music: they are "sustained and healed and nurtured by the translation of their experience into art above all in the music [ ... ] because all of the strategies of art are there." (as quoted in Gilroy, 1995: 78) Phillips goes beyond the issue of race, however, so voices of all lonely, displaced, isolated figures of the famous and anonymous, the dominant and dominated blend in the transcultural, transnational, multiracial and multiethnic "many-tongued chorus of common memory" (Phillips, 1995: 235) outside the confines of race, ethnicity and gender, singing a song of survival despite history's attempts to deprive them of their stories, testifying to Phillips's claim that no man's experience is more important than that of another (Schatteman, 2009: 65).

\section{MEMORY AS A CHRONOTOPE AND COMMUNITY}

Freed from the handcuffs of actual space and time, personal and collective memory in Phillips's oeuvre functions as a tissue among the narratives, as a polyphonic, heterotopian, heterogeneous community and an imaginary space of belonging for the displaced figures of his novels. According to Helen Thomas, 
this version of time - and space, we might add - "critiques and counterbalances the linear discourse by much of Western history and its metaphysics of progress" (Thomas, 2006: 7-8). Focusing on time, Thomas asserts that

[i]n its challenge of strictly linear concept of time progression, memory takes on an essential, critical role. By enabling certain experiences to be 'stretched' over time, memory endeavours to counteract tyrannies of cultural erasure instigated by historical genocides such as slavery or the Holocaust (Thomas, 2006: 8).

In this context, memory blurs and even cancels the borders of time and space and is further meant to span the gap between racial, ethnic, class, gender and other polarities commonly (ab)used to stir up conflict. Different historical periods and places are brought to the same plane to transform memory into a peculiar chronotope, and bring it close to Wilson Harris's concept of liminal gateway society in between worlds.

Phillips is, of course, by no means the first to have established links between the dispersal of Jews and Africans. Helen Thomas lists $19^{\text {th }}$ and $20^{\text {th }}$-century works such as William Mavor's History of the Dispersion of the Jews; of Modern Egypt; and of other African Nations (1802), James Africanus Horton's West African Countries and Peoples (1868), Edward Wilmot Blyden's Christianity, Islam and the Negro Race (1887), Sir Henry Johnston's The Negro in the New World (1910), or W.E.B du Bois's Dusk of Dawn (1940), all of which focus on the transatlantic slave trade and "the pain of segregation" (Thomas, 2006: 1) experienced by the African diaspora, some linking it with the dispossession of Jews. As Thomas states, Phillips's writing also continues in the line of theoretical ideas of thinkers like Frantz Fanon, Paul Gilroy or Stuart Hall, engaging in a fictional exploration of "the psychological effects of alienation, migration and dispossession" (Thomas, 2006: 3).

Although Phillips predominantly deals with victims, he does not limit his perspective to their voices alone - the slave trader in Crossing the River and the daughter of a slave owner in Cambridge feature as major characters - or "his memory to the suffering of the victim", to borrow Dereck Walcott's phrase (as quoted in Ashcroft et al., 2003: 371). Thus he avoids the risk of what Walcott calls servitude to the muse of history or historical truth, which would easily turn his novels into a literature of recrimination, despair or revenge written by some descendants of slaves, as opposed to a literature of remorse by the descendants of masters (Ashcroft et al., 2003: 371), exemplified by Nadine Gordimer, among others.

In his epic work The Golden Fleece, Borislav Pekić writes that the reverse side of political history is the history of sweat and toil. While political history is written in sweat, the history of sweat and toil is not written but lived. Dedicating himself to this lived history, found only in memory, Phillips stops short of becoming an apologizer, neither explaining nor forgiving history, as Walcott puts it (Ashcroft 
et al., 2003: 371). His compassion for the oppressor as well as the oppressed undermines both colonial and postcolonial biases, indicating, for instance, that a slave trader is not by default a "bad guy", since he too can be seen as a victim of historical circumstances (Schatteman, 2009: 62). This is another point which Phillips shares with Dereck Walcott, who sees both slaves and slave buyers as primarily "men acting as men" (as quoted in Ashcroft et al., 2003: 374). Having established his imagined community in memory across and beyond nations or cultures, beyond borders of all kinds, especially those between the high and low, superior and inferior, Phillips has managed to construct a form of symbolical shelter for "survivors' voices [ ... ] hurt but determined" (Phillips, 1995: 237), and reach across the rifts that all too often divide us.

Arijana Luburić Cvijanović

\section{SEĆANJE U DELU KARILA FILIPSA: UTOČIŠTE I/ILI TAMNICA?}

\section{REZIME}

Sećanje i rememoracija bili su od presudnog značaja za (re)konstrukciju postkolonijalnih identiteta u jeku oživljavanja pretkolonijalnih istorija i kultura u ranoj postkolonijalnoj književnosti. S postepenim preusmeravanjem pažnje na pitanja konstrukcije identiteta u društvima novog kolonijalizma, značaj rememoracije je počeo da jenjava dok sećanje i dalje progoni likove savremene postkolonijalne proze. Tu tendenciju ilustruje delo Karila Filipsa čiji junaci prate tokove sećanja na prošle živote, u potrazi za utočištem od gubitka, usamljenosti izgnanstva i različitih vidova marginalizacije, rizikujući da ostanu trajno zatočeni u lavirintima trauma iz prošlosti. Premda povlačenje u sećanje sprečava pojedine Filipsove likove u težnji da se prilagode sredini, sećanje u selokupnom njegovom delu služi kao stecište sudbina preživelih u pogromima. Ono predstavlja jednu polifonijsku, heterotopijsku i heterogenu imaginarnu zajednicu kojoj njegovi izmešteni, obeskorenjeni protagonisti pripadaju. Cilj ovog rada jeste da se ispita funkcija sećanja u Filipsovoj viziji, te da se istraži kako ustanovljeni prostor sećanja premošćuje jaz između polariteta obeleženih vrednosnim sudovima.

Ključne reči: Karil Filips, istorija, sećanje, postkolonijalno, rememoracija. 


\section{REFERENCES}

Ashcroft, B., Griffiths G., \& Tiffin H. (Eds.) (2003). The Post-colonial Studies Reader. London: Routledge.

Bhabha, H. (2003). Nation and Narration ( $2^{\text {nd }}$ edition). London: Routledge.

Coetzee, J. M. (2008). Inner Workings: Essays 2000 2005. London: Vintage.

Coetzee, J. M. (2002). Stranger Shores: Essays 1986 - 1999. London: Vintage.

Gilroy, P. (1995). The Black Atlantic: Modernity and Double Consciousness. Cambridge, MA: Harvard University Press.

Halpern, K., \& Ruano-Borbalan Ž. K. (2009). Identitet(i): Pojedinac, grupa, društvo. Beograd: Clio.

King, B. (2004). The Internationalization of English Literature. Oxford: Oxford University Press.

Ledent, B. (2002). Caryl Phillips. Manchester: Manchester University Press.

Phillips, C. (1993). Cambridge. New York: Vintage.

Phillips, C. (1995). Crossing the River. New York: Vintage.

Phillips, C. (2004). A Distant Shore. London: Vintage.

Phillips, C. (1999). Higher Ground. London: Faber and Faber.

Phillips, C. (1998). The Nature of Blood. Toronto: Vintage Canada.

Rushdie, S. (1992). Imaginary Homelands. London: Granta.

Schatteman, R. (Ed.) (2009). Conversations with Caryl Phillips. Jackson: University Press of Mississippi.

Thomas, H. (2006). Caryl Phillips. Tavistock: Northcote. 